\title{
Major and minor bio-element status in children with febrile seizure
}

\author{
Akbayram $\mathrm{S}^{1}$, Cemek $\mathrm{M}^{2}$, Büyükben $\mathrm{A}^{3}$, Aymelek $\mathrm{F}^{3}$, Karaman $\mathrm{S}^{1}$, Yilmaz $\mathrm{F}^{3}$, Dogan $\mathrm{M}^{1}$, \\ Caksen $\mathrm{H}^{1}$
}

Department of Pediatrics, Yuzuncu Yil University, Faculty of Medicine, Van, Turkey. drsinanakbayram@gmail.com

\begin{abstract}
Febrile seizures (FS) are the most common cause of seizures in children. The exact etiopathogenesis is unknown but involves factors like genetic predisposition and alterations in the levels of neurotransmitters and some trace elements. The study includes 48 consecutive children with FS, and 55 healthy age matched control subjects. Calcium, magnesium and potassium concentrations in the febrile study group were lower than in the control group $(p<0.05)$. Iron and Gallium levels in the study group were lower than in the control group $(p<0.01)$. Serum Selenium $(p<0.001)$, Zinc $(p<0.001)$ and Strontium $(p<0.05)$ levels were significantly decreased in the study group when compared to the control group. There was no significant difference between the control and study groups in Serum Barium, Beryllium and Copper levels $(p>0.05)$. The aim of the present prospective analytical case-control study was to determine whether there was any change in element levels in children with FS (Ref. 33). Full Text in PDF www.elis.sk.

Key words: febrile seizures, children, trace elements.
\end{abstract}

Febrile seizures (FS) are defined as an event during infancy or childhood, usually between 3 months and 5 years of age, associated with fever and without any evidence of intracranial infection or a definite cause for the seizure $(1,2)$. As the mechanisms underlying FS have multifactorial etiology, and so far remain unclear, its genetic causes are being studied (3-5). However, FS represents the point between a low seizure threshold and genetic components, recognized to be susceptible for FS and caused by mutations in several gene maps, such as FEB-1 to FEB-4 (5-7). Moreover, some mutations causing neural hyperexcitability could be responsible for FS especially with polygenic multifactorial genetic trait $(5,6,8)$.

Bio-elements as trace and major elements refer to chemical minerals required in different quantities by an organism to maintain its normal physiological function (9). Function of bio-elements in cells is generally complex and these functions in different ways. Cells require metal ions as co-factors of metalloproteins. Most metal ions are directly incorporated into their cognate sites in proteins involved in various cellular pathways. However, some metal ions become a part of the prosthetic groups, co-factors, or complexes prior to insertion of these moieties into the target proteins $(10,11)$. Several essential elements play important roles in redox reactions, in connective tissue or cell membranes, in stabilization of biologi-

${ }^{1}$ Department of Pediatrics, Yuzuncu Yil University Faculty of Medicine, Van, Turkey, ${ }^{2}$ Department of Chemistry (Biochemistry Division), Faculty of Sciences and Arts, Kocatepe, and ${ }^{3}$ Department of Chemistry (Biochemistry Division), Cay Vocational School, Afyon Kocatepe University, Afyonkarahisar, Turkey

Address for correspondence: S. Akbayram, MD, Yuzuncu Yil University, Faculty of Medicine, Department of Pediatrics, 65200, Van, Turkey. Phone: +0.90 .505 .2725659$ cal molecules and in control of biological processes by facilitating the binding of molecules to receptor sites on cell membranes (12).

In this study, serum major and trace elements were studied in children with FS. The aim of the present prospective analytical case-control study was to determine whether there was any change in element levels in children with FS.

\section{Patients and methods}

The study included 48 consecutive children with FS, and 55 healthy age matched control subjects, followed in Yuzuncu Yil University, Faculty of Medicine, Department of Pediatrics. All these children had normal neurological examination. The local ethical committee of our hospital approved the study.

Blood samples were collected from the patients with FS and healthy control subjects, which were included in the study. It was obtained from children with FS within a few hours after seizure attack. Venous blood samples were obtained from each subject and transferred to normal tubes. Serum was obtained by centrifugation at $2000 \mathrm{~g}$ for $10 \mathrm{~min}$ of blood samples taken without anticoagulant and stored at $-20{ }^{\circ} \mathrm{C}$ until analysis date.

Hydrogen peroxide, nitric acid, perchloric acid, and suprapur ICP multielement standard solutions were purchased from Merck. All other chemicals and reagents used in this study were of analytical grade. Ultra-distilled water was used as the solvent.

All the plastic containers were previously washed in $10 \%$ nitric acid (ultrapure grade) and then repeatedly rinsed with ultra water. Decomposition of the organic matrix in the tissue samples were performed using a microwave oven. A Milestone Start D (Italy) microwave oven equipped with a Pro 24 High Throughput Rotor 
and a temperature control program was used to digest simultaneously 24 samples of tissue in one cycle. The rest of the elements were determined after mineralization of the samples. The serum samples of exactly $0.1 \mathrm{~g}$ were weighed (wet weight) and put in high-pressure Teflon vessels and added with $3 \mathrm{ml}$ of concentrated nitric acid, $1 \mathrm{ml}$ of hydrogen peroxide and $0.5 \mathrm{ml}$ perchloric acid (ultrapure, Merck, Germany). The Teflon vessels were then sealed with a Teflon lid and put into the steel bombs, which were sealed with exactly the same momentum. The mixture in the bombs was heated in a microwave oven according to the following sequence (temperature/time): $90^{\circ} \mathrm{C} / 15 \mathrm{~min}, 120^{\circ} \mathrm{C} / 15 \mathrm{~min}, 140^{\circ} \mathrm{C} / 60 \mathrm{~min}$, $150{ }^{\circ} \mathrm{C} / 60 \mathrm{~min}$. After cooling to room temperature, this solution was quantitatively transferred and adjusted in a flask to $10 \mathrm{~mL}$ with 18.2 M $\Omega . c m$ ultra water (Millipore DirectQ UV, Japan). Trace and major element concentrations in the digest were determined by inductively coupled plasma-optical emission spectroscopy (ICPOES; Spectro Genesis, Germany). The operating conditions of the ICP-OES are given in Table 1. Accuracy of the analysis was verified by the determination of the mineral content of the ICP multielement standard obtained from Merck (Germany).

\section{Statistical analysis}

Statistical analysis was performed with the Statistical Package for the Social Sciences for Windows (SPSS version 10.0, Chicago, IL, USA). Data were expressed as the mean \pm standard deviation (SD). Student's $t$-test was used to compare the mean values of different bio-element parameters between the study and control groups. In all data analysis, a value of $\mathrm{p}<0.05$ was considered statistically significant.

\section{Results}

A total of 48 children 17 girls (35.5\%) and 31 boys (64.5\%), aged 0.5 years to 5 years (mean $22.2 \pm 13.7$ months) with FS and 55 healthy children 28 girls ( $51 \%$ ) and 27 boys ( $49 \%$ ), aged 0.5 years to 5 years (mean $28.8 \pm 17.0$ months) were included in the study.

Table 2 shows serum major element levels in the control and study groups. Calcium $(\mathrm{Ca})$ and potassium $(\mathrm{K})$ concentrations in the febrile study group were lower than the control group $(\mathrm{p}<0.05)$. Magnesium $(\mathrm{Mg})$ concentrations was also statistically decreased in the study groupwhen compared to the control group $(\mathrm{p}<0.01)$.

Serum trace element levels in the control and study groups are shown in the Table 3. Iron (Fe) and Gallium (Ga) levels in the study group were lower than in the control group $(\mathrm{p}<0.01)$. Serum Selenium (Se) $(\mathrm{p}<0.001)$, Zinc $(\mathrm{Zn})(\mathrm{p}<0.001)$ and Strontium $(\mathrm{Sr})$ $(p<0.05)$ levels were significantly decreased in the study group when compared to the control group. There was no significant difference between the control and study groups in Serum Barium $(\mathrm{Ba})$, Beryllium $(\mathrm{Be})$ and Copper $(\mathrm{Cu})$ levels $(\mathrm{p}>0.05)$.

\section{Discussion}

FS are the most common cause of seizures in children. It has been known since ancient times that seizures frequently accompany fever in young children. The exact pathogenesis is unknown but involves factors, such as genetic predisposition and alterations in the levels of neurotransmitters and some trace elements $(8,13$, 14). There is a growing evidence that the balance between the bioelements, such as $\mathrm{Mg}, \mathrm{Ca}, \mathrm{Fe}, \mathrm{Cu}, \mathrm{Zn}$, and $\mathrm{Se}$ in the nervous tissue is of crucial importance for maintaining human health (15). In biological systems, these mainly metallic elements are usually bound to proteins. Metals in metalloproteins are components of enzymatic systems, and fulfill structural and storage functions. Hence, these elements are responsible for various metabolic processes, including those occurring in the brain (16). Existing evidence suggests that epileptic seizures significantly change the metabolism and distribution of trace elements in the nervous tissue (17-19). On the other hand, metal contents determine susceptibility to convulsions (20).

In the present study, we investigated the levels of trace and major element concentrations in children with FS. Our results of this study showed that bio-element levels were affected in children with FS. The changes in bio-elements in FS explained the respond of the metabolism. Amiri et al found significantly low levels of Se and $\mathrm{Zn}$ in patients with FS (21).

Zinc is a component of more than 300 different enzymes that function in many aspects of cellular metabolism, involving metabolism of proteins, lipids, and carbohydrates (22). Moreover, according to different reports, $\mathrm{Zn}$ is considered either as a convulsion promoting factor or as an anticonvulsant $(23,24)$. Decreased $\mathrm{Zn}$ levels have been reported in the serum of epileptic patients and in the cerebrospinal fluid of infants with benign postnatal seizures $(25-27)$. In our study, we found that serum $\mathrm{Zn}(\mathrm{p}<0.001)$ levels were significantly decreased in children with FS.

It was noted that there was a significant reduction in serum $\mathrm{Mg}$ values in FS in comparison to encephalitis and fever with meningismus. Papierkowski et al (28) also reported similar findings in their series. In our study, we found that $\mathrm{Mg}(\mathrm{p}<0.01)$ levels were significantly decreased in the FS group.

Fe is involved in the metabolism of several neurotransmitters, and monoamine and aldehyde oxidases are reduced in irondeficiency (29). Kobrinsky et al (30) reported that iron deficiency raises the threshold for seizures. In our study, $\mathrm{Fe}(\mathrm{p}<0.01)$ levels were significantly decreased in the study groupwhen compared to the control group.

$\mathrm{Cu}$ is an essential trace element in living organisms (31). Decreased $\mathrm{Cu}$ levels in given regions of the animal brain after an acute phase of epileptic seizures may suggest the activity of $\mathrm{Cu}$. The observed decrease could also be the result of postepileptic changes in the permeability of brain blood barrier leading to a massive outflow of the elements from the tissue affected by seizures (32). Donaldson et al (33) showed that $\mathrm{Cu}$ exhibits an inhibitory activity against $\mathrm{Mg}^{2+}$-ATPase, as well as $\mathrm{Na}^{+}-\mathrm{K}^{+}$-ATPase enzymes found in abundance in hippocampus and hypothalamus and disrupting the mechanisms, which maintain the correct intraneuronal sodium and potassium ratio. This disruption is associated with a membrane instability and paroxysmal discharges. In our study, no significant difference was found between the control and study groups for serum $\mathrm{Cu}$ levels.

In conclusion, our findings showed that some trace elements including, $\mathrm{Ca}, \mathrm{K}, \mathrm{Mg}, \mathrm{Fe}, \mathrm{Ga}$, Se, $\mathrm{Zn}$ and $\mathrm{Sr}$ were decreased in 
children with FS. Therefore, we suggest that deficiencies of these elements may be responsible for the etiopathogenesis in some children with FS.

\section{References}

1. Fallah R, Golestan M. Role of laboratory diagnostic tests in first febrile seizure. J Pediatr Neurol 2008; 2 (6): 129-132.

2. Ganesh R, Janakiraman L. Serum zinc levels in children with simple febrile seizure. Clin Pediatr (Phila) 2008; 47 (2): 164-166.

3. Gunduz Z, Yavuz I, Koparel M, Kumandas S, Saraymen R. Serum and CSF zinc levels in children with febrile convulsion. Acta Pediatr Jap 1996; 38 (3): 237-241.

4. Moayedi AR, Tasnim EE, Moayedi F. Febrile seizures: Factors affecting risk of recurrence. J Pediatr Neurol 2008: 6 (4): 341-344.

5. Mollah MA, Rakshit SC, Anwar KS, Arslan MI, Saha N, Ahmed S, Azad K, Hassan T. Zinc concentration in serum and cerebrospinal fluid simultaneously decrease in children with febrile seizure: findings from a prospective study in Bangladesh. Acta Paediatr 2008; 97 (12): 1707-1711.

6. Peiffer A, Thompson J, Charlier C, Otterude B, Varbil T, Pappas C, et al. A locus for febrile seizure (FEB3) maps to chromosome 2q23-24. Ann Neurol 1999; 46 (4): 671-678.

7. Omran MS, Khalilian E, Mehdipour E, Juibary AG. Febrile seizures in North Iranian children: Epidemiology and clinical feature. J Pediatr Neurol 2008; 1 (6): 39-42.

8. Burhanoglu M, Tutuncroglu S, Coker C, Tekgul H, Ozgur T. Hypozincaeia in febrile convulsion. Eur J Pediatr 1996; 155 (6): 498-501.

9. Mertz W. The essential trace elements. Science 1981; 213 (4514): 1332-1338.

10. Goldhaber SB. Trace element risk assessment: essentiality vs. toxicity. Regul Toxicol Pharmacol 2003; 38 (2): 232-242.

11. Mendel RR, Smith AG, Marquet A, Warren MJ. Metal and cofactor insertion. Nat Prod Rep 2007; 24 (5): 963-971.

12. Mertz W. Review of the scientific basis for establishing the essentiality of trace elements. Biol Trace Elem Res 1998; 66 (1-3): 185-191.

13. Rating D, Siemes H, Loscher W. Low CSF GABA concentration in children with febrile convulsions, untreated epilepsy, and meningitis. J Neurol 1983; 230: 217-225.

14. Mollah MA, Dey PR, Tarafdar SA, Akhter S, Ahmed S, Hassan T, Begum NA, Nahar N. Zinc in CSF of patients with febrile convulsion. Indian J Pediatr 2002; 69 (10): 859-861.

15. Lynes MA, Kang YJ, Sensi SL, Perdrizet GA, Hightower LE. Heavy metal ions in normal physiology, toxic stress, and cytoprotection. Ann N Y Acad Sci 2007; 1113: 159-172.

16. Formigari A, Irato P, Santon A. Zinc, antioxidant systems and metallothionein in metal mediated-apoptosis: biochemical and cytochemical aspects. CompBiochem Physiol C Toxicol Pharmacol 2007; 146: 443-459.
17. Papavasiliou PS, Miller ST. Generalized seizures alter the cerebral and peripheral metabolism of essential metals in mice. Exp Neurol 1983; 82: $223-236$.

18. Carl GF, Critchfield JW, Thompson JL, McGinnis LS, Wheeler GA, Gallagher BB, Holmes GL, Hurley LS, Keen CL. Effect of kainateinduced seizures on tissue trace element concentrations in the rat. Neuroscience 1989; 33 (1): 223-227.

19. Carl GF, Critchfield JW, Thompson JL, Holmes GL, Gallagher BB, Keen CL. Genetically epilepsy-prone rats are characterized by altered tissue trace element concentrations. Epilepsia 1990; 31 (3): 247-252.

20. Hirate M, Takeda A, Tamano H, Enomoto S, Oku N. Distribution of trace elements in the brain of EL (epilepsy) mice. Epilepsy Res 2002; 51 (1-2): 109-116.

21. Amiri M, Farzin L, Moassesi ME, Sajadi F. Serum trace element levels in febrile convulsion. Biol Trace Elem Res 2010; 135 (1-3): 38-44.

22. Parkin G. Chemistry. Zinc-zinc bonds: a new frontier. Science 2004; 305 (5687): 1117-1118.

23. Williamson A, Spencer D. Zinc reduces dentate granule cell hyperexcitability in epileptic humans. Neuroreport 1995; 6 (11): 1562-1564.

24. Pei Y, Zhao D, Huang J, Cao L. Zinc-induced seizures: a new experimental model of epilepsy. Epilepsy 1983; 24 (2): 169-176.

25. Barbeau A, Donaldson J. Zinc, taurine and epilepsy. Arch Neurol 1984; 30 (1): 522-528.

26. Goldberg HJ, Sheehy EM. Fifth day fits: An acute zinc deficiencv svndrome? Arch Dis Child 1982; 57 (8): 633-635.

27. Olatunbosun DA, Akindele MO, Adeniyi FA, Bademosi O. Serum copper and zinc levels in epilepsy. Nigerian Med J 1978; 8 (2): 124-125.

28. Papierkowski A, Mroczkowska-Juchkiewicz A, Pawlowska-Kamieniak A, Pasternak K. Magnesium and zinc levels in blood serum and cerebrospinal fluid in children with febrile convulsions. Pol Merkuriusz Lek 1999; 6 (33): 138-140.

29. Parks YA, Wharton BA. Iron deficiency and the brain. Acta Pediatr Scand 1989; 55 (Suppl 361): 71-77.

30. Kobrinsky NL, Yager JY, Cheang MS, Yatscoff RW, Tenenbein M. Does iron deficiency raise the seizure threshold? J Child Neurol 1995; 10 (2): 105-109.

31. Chwiej J, Winiarski W, Ciarach M, Janeczko K, Lankosz M, Rickers K, Setkowicz Z. The role of trace elements in the pathogenesis and progress of pilocarpine-induced epileptic seizures. J Biol Inorg Chem 2008; 13 (8): 1267-1274.

32. Sahin D, Ilbay G, Ates N. Changes in the blood-brain barrier permeability and in the brain tissue trace element concentrations after single and repeated pentylenetetrazole-induced seizures in rats. Pharmacol Res 2003; 48 (1): 69-73.

33. Donaldson J, St Pierre T, Minnich J, Barbeau A. Seizures in rats associated with divalent cation inhibition of NA+-K+- ATP'ase. Can J Biochem 1971; 49 (11): 1217-1224. 